$\operatorname{mg} 0.5 \cdot 160$

E. S. LIBKAKX. COP. 2

CONNECTICUT

AGRICULTURAL

EXPERIMENT

STATION

NEW HAVEN, CONN.

BULLETIN 165, NOVEMBER, 1909.

ENTOMOLOGICAL SERIES, NO. I5.

\title{
The San José Scale and Methods of Controlling It.
}

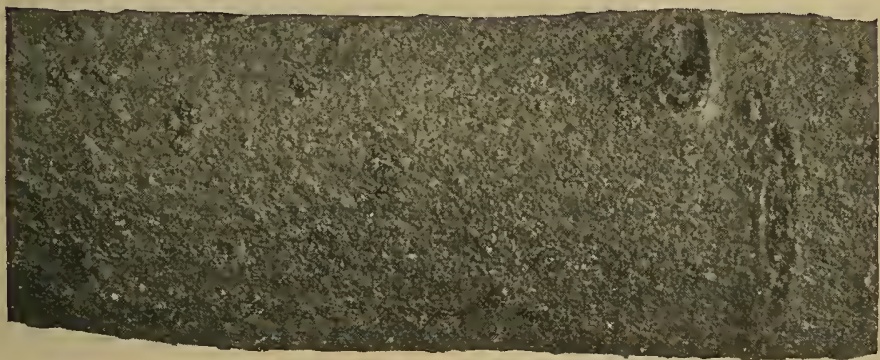

FIG. I.-San José Scale on apple bark. Natural size.

CONTENTS.

Officers and Staff of Station..........

The San José Scale and Methods of Controlling It ....

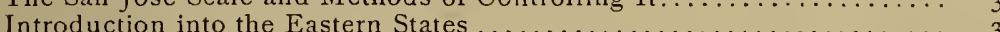

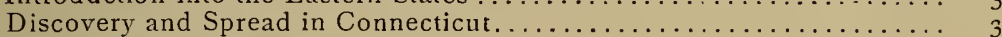

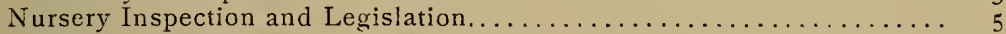

General A ppearance of the Insect $\ldots \ldots \ldots \ldots \ldots \ldots \ldots \ldots \ldots \ldots \ldots \ldots \ldots \ldots \ldots \ldots$

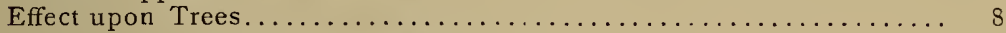

How the Scale Spreads from Tree to Tree................... 8

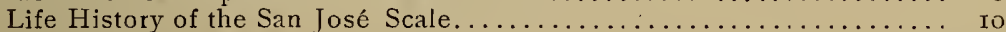

Food Plants ................................... II

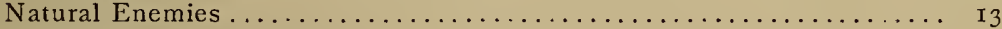

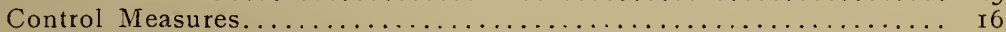

Fumigating Nursery Stock . . . . . . . . . . . . . . . . . . . . 6

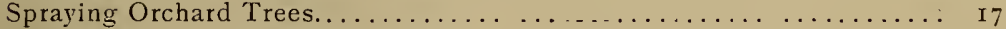

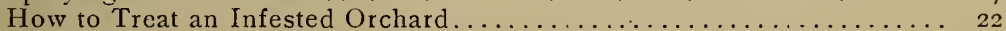

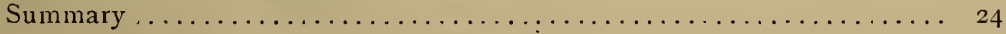

The Bulletins of this Station are mailed free to citizens of Connecticut who apply for them, and to others as far as the editions permit. 


\section{CONNECTICUT AGRICULTURAL EXPERIMENT STATION.}

\section{OFFICERS AND STAFF.}

BOARD OF CONTROL.

His Excellency, Frank B. Weeks, Ex officio, President.

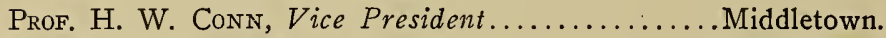

Prof. W. H. Brewer, Secretary.................. Hew Haven.

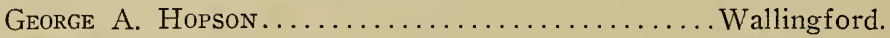

Charles M. Jarvis..............................

Frank H. Stadtmueller.................... Elmwood.

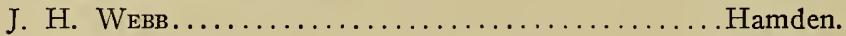

E. H. Jenkins, Director and Treasurer............ New Haven.

\section{STATION STAFF.}

Chemists.

Analytical Laboratory.

John P. Street, M.S., Chemist in Charge.

E. Monroe Balley, M.S.

C. B. Morrison, B.S.

R. B. RoE, A.B.

C. E. Shepard.

Laboratory for the Study of Proteids.

T. B. Osborne, Ph.D., Chemist in Charge.

\section{Botanist.}

G. P. Clinton, S.D.

Entomologist.

W. E. Britton, Ph.D.

Assistant in Entomology.

B. H. Walden, B.Agr.

Forester.

Samuel N. Spring, M.F.

Seed Testing.

MARY H. JAGGER.

Stenographers and Clerks.

Miss V. E. Cole.

Miss L. M. Brautlecht.

Miss E. B. Whittlesey.

In charge of Buildings and Grounds.

William VeItch.

Laboratory Helper.

Hugo LANGE.

Sampling Agent.

V. L. Churchill, New Haven. 


\section{THE SAN JOSÉ SCALE AND METHODS OF CON- TROLLING IT.*}

By W. E. Britton, State Entomologist.

No other insect has caused so much destruction in fruit orchards throughout the country as the San José Scale (Aspidiotus perniciosus Comst.). This scale was first noticed by fruit shippers near San José, Cal., and was described by Prof. J. H. Comstock, in 1880 . It was at that time doing much damage in California, and Prof. Comstock regarded it as the most destructive scale-insect which he had seen.

Its original home is probably in China.

\section{Introduction into the Eastern States.}

The scale was first found in the Eastern States, in August, I893, at Charlottesburg, Va. In March, I894, an infested locality was found at Riverside, Md. In both cases, the introduction of the insect was traced to New Jersey nurseries, which had received the scale on nursery stock from California. Another infested area was discovered in March, I894, at De Funiak Springs, Fla. Shortly afterwards Indiana, Pennsylvania, New Jersey, New York, Georgia, Ohio, Delaware and, in the summer of 1895, Alabana, Louisiana, Connecticut and Massachusetts were added to the list of infested states. At the present time, the San José Scale exists in nearly every portion of the United States, the extreme Northern states alone, perhaps, being exempt.

\section{Discovery and Spread in Connecticut.}

About twenty years ago the San José or pernicious scaleinsect was introduced into Connecticut on nursery stock from New Jersey. It escaped notice, however, until June I2th, I895,

* In I9oI, Bulletin I35 was issued on this subject but is now out of print. As the control methods have changed appreciably since that time, the present bulletin is a revised and enlarged edition of the old, including the latest remedies. 
when it was discovered at New London by Dr. W. C. Sturgis, botanist of this Station. The insect had then been multiplying for four years in the orchard and garden of Mr. J. L. Raub, and several trees had been killed by it. A study of the locality was made and a bulletin was issued, calling attention to the presence of the insect in Connecticut, describing its appearance and injuries, and giving the best remedies known at that time. (See Bulletin No. I2I, July, I895.)

Soon after, specimens were received from Hartford and Bridgeport. During 1896 , additional centers of infection were found at Darien, New Haven, Groton, Mystic, Farmington, New Britain, Plantsville, and in the following year, Meriden, Wallingford, Hamden, Woodbridge and Greenwich were added to the list. The scale was found in Ivoryton, Nichols, Cheshire, Burnside and Rowayton during 1898 , and in several new localities in New Haven, Hartford and Bridgeport. Previous to July Ist, I90I, when the Insect Pest Law became operative, the San José Scale had been found in seventy-eight localities in this State.

At the present time it is found practically all over the State and though some orchards are still uninfested, it is doubtful if there is a single town or village which does not harbor some infested trees or shrubs.

In a few of the places, the insect was discovered before it had infested more than one or two trees. The immediate destruction of these infested trees has probably wiped out the pest from a very few localities, but in most cases the scale had spread to a serious degree before it was discovered, and many trees have been killed and a still greater number badly injured by its attacks.

In the cities and larger towns the scale has destroyed many fruit trees and ornamental shrubs. A number of large peach orchards were ruined by it. Apple orchards have also been severely injured, but the principal growers know how to control it and do not fear it as they did a few years ago. The annual spraying is a part of their orchard practice and no more to be neglected than cultivation, pruning or fertilizing; in fact it is even more important, as actual damage will result if neglected. 


\section{Nursery Inspection and LegisLation.}

Inasmuch as the San José Scale has been distributed chiefly by means of nursery stock, a system of nursery inspection has been established in nearly all of the states. Previous to I896 several states had passed laws requiring that each box or package of nursery stock shipped into those states should be accompanied by a certificate of inspection issued by a duly authorized inspector. States not provided with an inspection

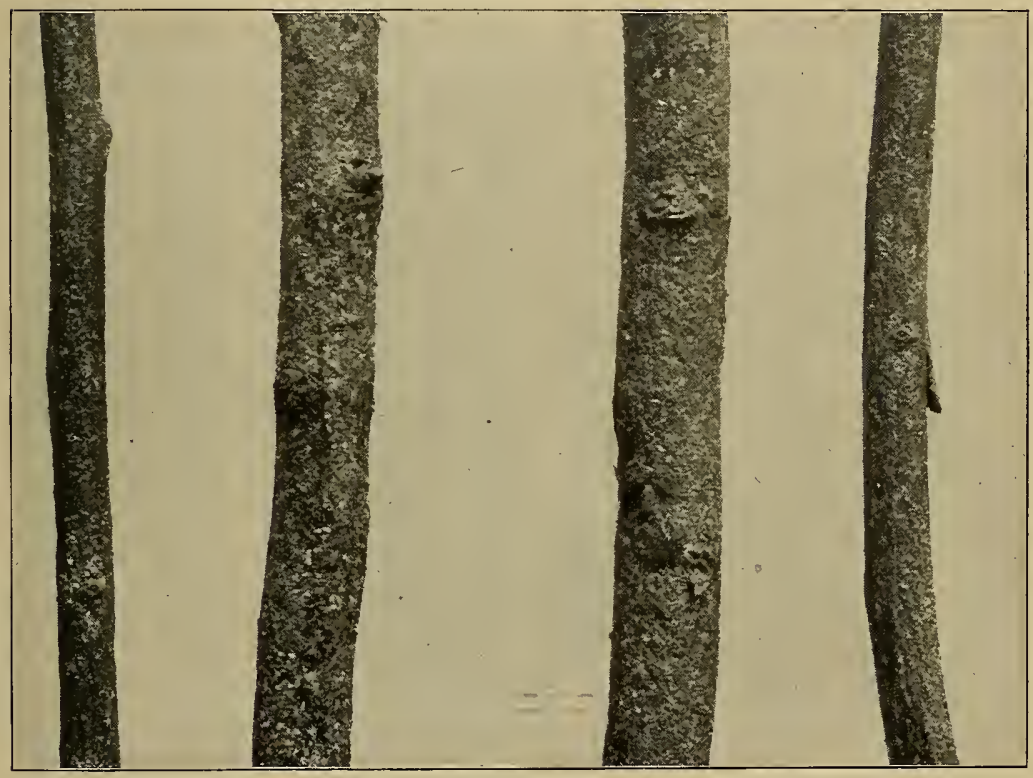

FIG. 2.-Plum Twigs nearly coated over by San José Scale. Natural size.

system soon realized the necessity of having one, both for their own protection and to enable their nurserymen to ship stock into the states where laws existed. Twenty-five states had already passed similar measures when Connecticut, in I90I, enacted an inspection law, which was amended slightly in I903. At the present time forty-five states and territories, including Hawaii and Porto Rico, have such laws, the only ones without them being Nevada, New Mexico and North Dakota. 
Though the San José Scale has been the exciting cause of most of the legislation, many other injurious insects as well as fungous diseases are debarred, and the inspections have prevented the spread of a number of very serious pests.

\section{General Appearance of the Insect.}

Usually the insect appears upon the bark as a greyish, rough coating, scarcely noticeable to the naked eye. (See Figures I and 2.) At first there are but few individuals, generally found clustered around the buds and at the branching of the twigs. Figure 4 shows how the scales collect in a groove or hollow in one side of a twig, as if they had sought a sheltered situation. As the trees become more thoroughly infested, the bark may be completely covered, and sometimes there are several layers of scales covering the bark. In such cases leaves and fruit are usually attacked. The young scales locate upon both sides of the leaf, along the ribs (see Figure 6), where they cause a reddish discoloration. This discoloration also occurs on fruit, and on the twigs, especially where there are but few individuals, and it extends through the bark to the wood. Where the insect is found upon the fruit, it seems to prefer the calyx and the stem cavities. Upon slightly infested trees the fruit is not attacked, but on trees which are badly infested the fruit is often so thoroughly covered as to present a very disgusting appearance. (See Figures 7 and 8.) If we examine the insect through a pocket lens, magnifying perhaps ten diameters, we see that it is distinctly circular in outline, somewhat raised above the bark, especially in the center, where there is a small nipple, differing in color from the other portion. If infested twigs are much handled, the outer layer is rubbed away from the nipple, leaving it a bright yellow color. Concentric circles are usually apparent between this nipple and the outside edge. The scaly covering is formed at the edge in concentric layers or additions. The covering of the male is different in shape from that of the female. While that of the female is nearly circular in outline, the armor of the full-grown male scale is nearly always elongated, with the nipple near one end, and the lines of formation are eccentric instead of concentric. (See Figure 3.) 
The color of the shell or covering varies greatly, sometimes being a light grey, sometimes being nearly black. It frequently turns dark if the insects are killed when half grown. If killed when fully grown, the shells often assume a light grey color,

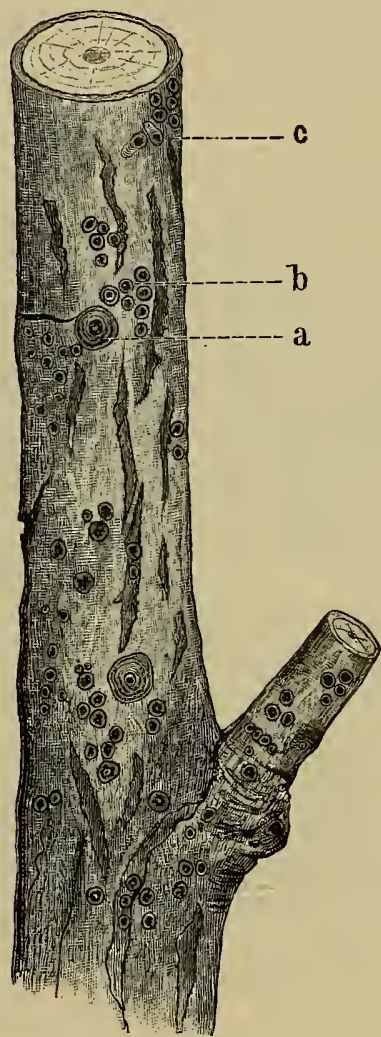

FIG. 3.-San José Scale on peach twig: a. mature female ; b. young females; c. immature males. About twice natural size.

and finally drop from the twigs. If we lift this shell or covering with a pin or point of a knife, we will see underneath a small yellow object, oval or circular in outline, which appears like a bit of yellow jelly. This is the insect proper and is shown in the illustration in Figure 5. 


\section{EFFECT UPON TREeS.}

The effect on the vitality of the tree is not apparent until the twigs become nearly covered by the insects. Then it may be noticed that the tree seems unthrifty, but the scale is so inconspicuous that frequently the tree loses some of its branches or dies before the cause of the trouble is discovered. Frequently we see a peach tree which has been severely injured, and the branches are dead, but the trunk is still alive and making an effort to grow a new top. This form of injury is often seen, and frequently the owner does not discover the cause until his

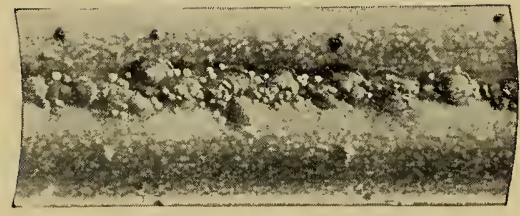

FIG. 4.-San José Scale on peach twig. Twice natural size.

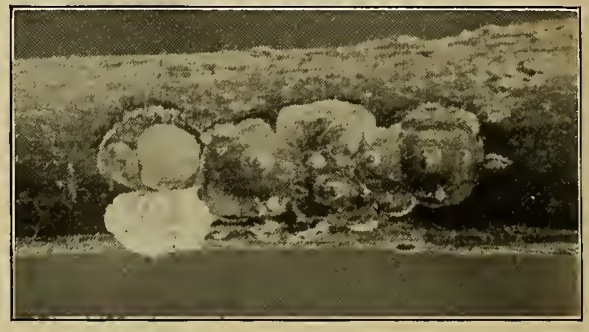

FIG. 5.-Female with shell raised to show insect beneath. Much enlarged.

trees reach this condition. The length of time required to kill a tree depends on various factors. In certain seasons the species multiplies much more rapidly than in others, depending undoubtedly upon the weather and the abundance of natural enemies. The writer has known of several localities where ornamental plants were attacked and no measures taken to destroy the scale, yet for two or three years the insect has not spread to any appreciable extent. On the other hand, in certain orchards, it has spread with great rapidity in spite of vigorous combative measures. In Mr. Raub's garden at New London, large peach trees were killed by the scale in four years.

How the Scale Spreads from Tree to Tree.

The young scales crawl about for a few hours on the bark, and if the trees stand so close that the branches interlace, of course they can readily crawl from one to the other. They are 
scarcely able to crawl long distances from the trunk of one tree to another over the rough ground, but are often blown about on fallen leaves and may reach a different section of the orchard in that way. In cultivating nurseries, the workmen brush against the young trees, and it is quite possible for some of the young insects to be carried to other trees along the nursery rows.

In one case, the orchard became infested by hitching a horse to one of the trees, after the team had been in an infested

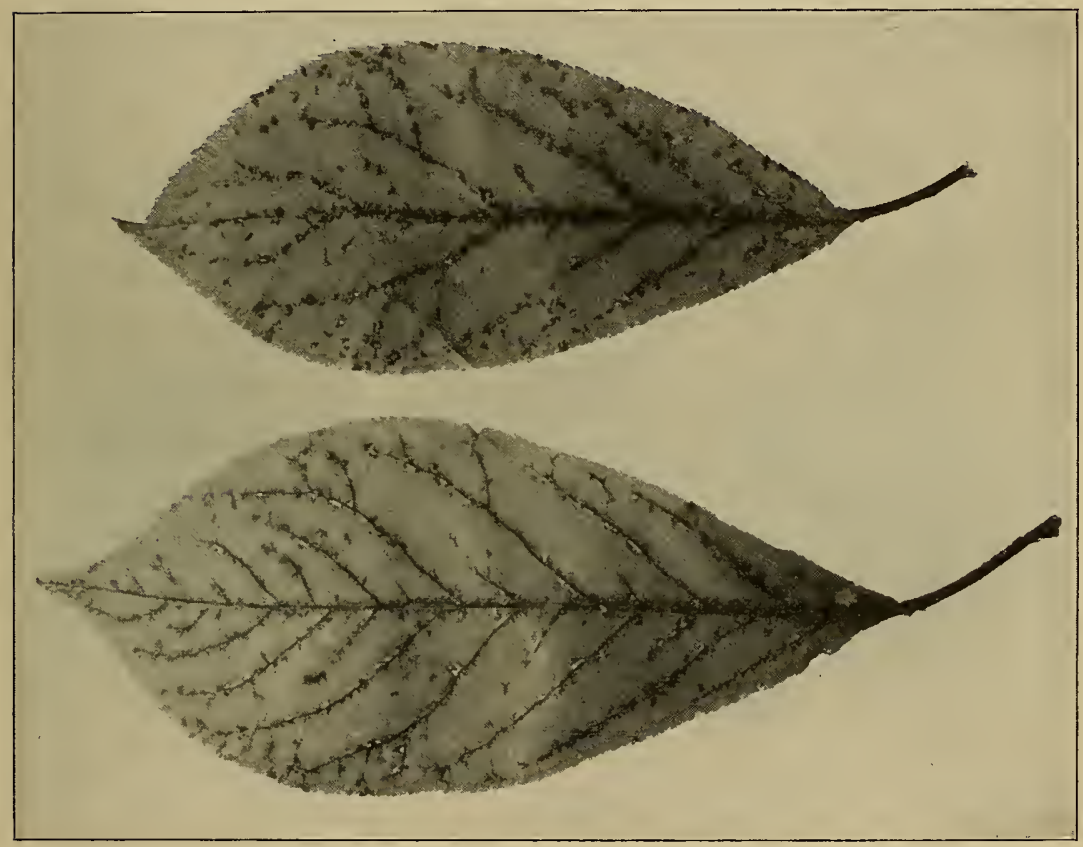

Fig. 6.-Infested plum leaves, showing the tendency of the insects to locate near the veins.

orchard three miles distant.* The throwing about of infested fruit may aid in distributing the pest. Also where parings of infested fruit are thrown out into gardens, there is danger that near-by trees may become infested.

As a rule, however, the insect is carried to distant trees either by other insects or upon the feet of birds.

* Bulletin No. 3, New Series, Division of Entomology, U. S. Department of Agriculture, Washington, D. C., p. 50. 


\section{Life History of the San José Scale.}

Both the males and females pass the winter in an immature state, and do not reproduce until the latter part of June in this latitude. The female does not lay eggs, but brings forth living young. The newly-born scales of both sexes crawl about for a few hours upon the twigs. They are provided with legs, eyes, antennæ and mouth-parts. After they have found a suitable place, they settle upon the bark, insert their beaks and begin to suck the juice from it. Legs and antennæ now disappear in both sexes, and the females lose their eyes. At first there is a white

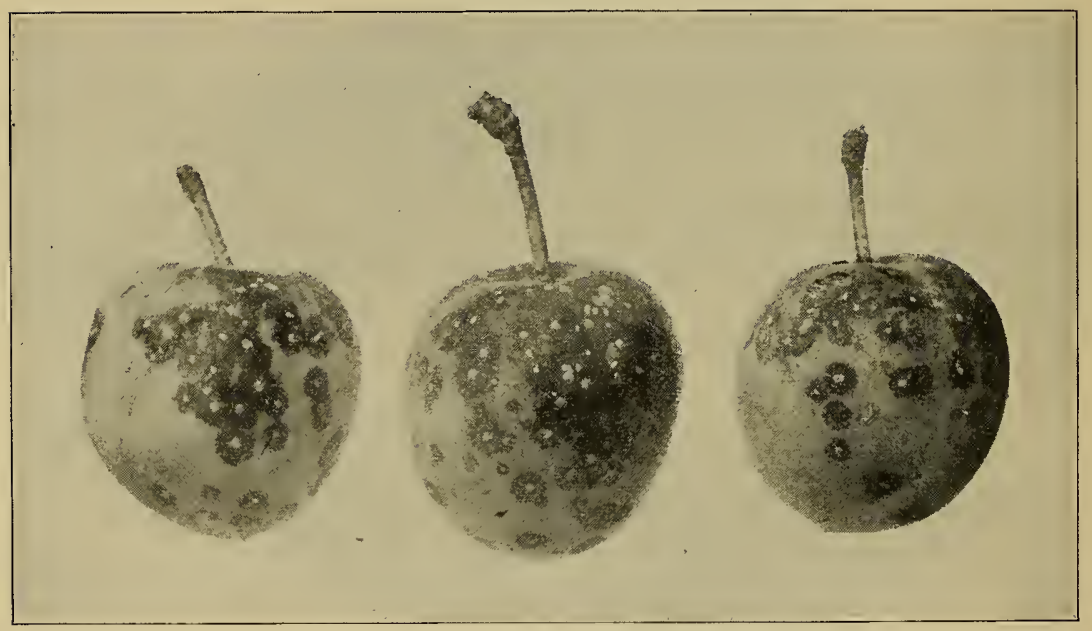

FIG. 7.-Infested plums showing the reddish discoloration caused by the insects.

waxy substance exuded, which has somewhat the appearance of wool. A little later this seems to melt down and the insect casts its skin. The skin, together with the waxy substance, forms the beginning of the shell or covering. After feeding for about four weeks, the insect reaches the full-grown stage. If a female, it then begins to bring forth its young, continuing for a period of about six weeks. The number of young produced by a single female varies from less than one hundred in the early part of the season to nearly six hundred in late summer. The male feeds until full-grown, passes through the pupa stage, and finally 
the adult comes forth from under the shell, provided with eyes, wings, legs, antennæ and organs of reproduction, but with no mouth-parts nor digestive system. He can, therefore, eat nothing after reaching the adult stage. His only mission is to mate with the female and die. The female, on the other hand, after becoming established upon the twig, loses legs, antennæ, and eyes, never again to be possessed of these organs, while its mouth-parts, digestive system and reproductive organs become very strongly developed. It cannot, therefore, move about, but feeds upon the juices of the plant and reproduces its kind. There are three complete generations each season in this latitude, and probably four in favorable seasons.

\section{Food Plants.}

Though the San José Scale is a pest chiefly of orchards, it must also be taken into account in the planting of shade and ornamental trees and shrubs, as the cost of caring for any extensive plantation will be much greater if it has to be treated each year to destroy the scale.

In 1902 the writer published* a rather extensive list of trees and shrubs, showing their susceptibility to the attacks of the San José Scale. Our experience since then prompts us to make a few modifications in the list, it being in the main correct. The following list is really an abridged edition of the former list, with common names used in preference to Latin names, and most of the specific names have been omitted. It is arranged for Connecticut, and may not hold good for other sections of the country.

List of Trees and Shrubs and their Susceptibility to the Attacks of the San José Scale.

\section{Badly Infested.}

Akebia.

Apple.

Apricot.

Basswood or Linden.

Beech, European (especially purple form).

Buckthorn (Rhamnus).
Cherry (all kinds except sour cherry).

Choke berry.

Cotoneaster sp.

Currant (all kinds).

Dogwood (Cormus sp. except florida).

\footnotetext{
* Report of this station for I902, page I32.
} 
Elm.

Hawthorn (Crataegus sp.).

Hop tree.

Lilac.

Mountain ash.

Osage Orange.

Peach.

Pear.

Photinia villosa.

Plum (all kinds).
Poplar (Populus sp.).

Quince (including Japanese).

Rose (some hardy species, espe. cially rugosa).

Shad-bush or June-berry (Amelanchier).

Spiræa (opulifolia, sorbifolia and Douglasii).

Walnut, Japanese.

Willow, several species.

Occasionally Infested, but not Injured.

Actinidia.

Alder.

Almond, Flowering.

Ash (Fraxinus sp.).

Birch.

Bittersweet (Celastrus).

Blackberry.

Box.

Button Bush (Cephalantus occidentalis).

Catalpa.

Cercidiphyllum Japonicum.

Chestnut.

Dewberry.

Dogwood, Flowering.

Elder (Sambucus).

Euonymus sp.

Gooseberry.

Grape (Vitis).

Hackberry (Celtis).

Honey Locust (Gleditschia).
Honeysuckle (Lonicera, some species).

Horsechestnut.

Kieffer pear.

Locust (Robinia).

Maple (Acer sp.) (especially Striped).

Mulberry.

New Jersey Tea (Ceanothus).

Pecan nut.

Pepperidge or Sour Gum (Nyssa).

Raspberry.

Rose (most species).

Sassafras.

Silver Thorn (Eleagnus).

Smoke bush (Rhus cotinus).

Sour Cherry.

Sumac.

Viburnum sp.

Virginia Creeper.

Walnut (Black and Persian).

Not Infested.

Ailanthus.

Althea.

Amorpha fruticosa.

Andromeda sp.

Arbor-vite.

Baccharis halimifolia.

Bald Cypress (Taxodium).

Barberry (all species).

Beech (American).

Bladder nut (Staphylea).
Blueberry (Vaccinium sp.).

Boston Ivy (Ampelopsis).

Butternut.

Buttonwood, Sycamore (Platanus).

Cedar.

Daphne sp.

Deutzia.

Dutchman's Pipe (Aristolochia).

English Ivy (Hedera helix).

Filbert or Hazel (Corylus sp.). 
Fir (Abies).

Forsythia sp.

Genista tinctoria.

Golden Chain (Laburmum).

Hemlock (Tsuga).

Hercules Club (Aralia spinosa).

Hickory (except Pecan).

Honeysuckle (most species).

Hop-Hornbeam or Ironwood (Ostrya).

Hornbeam (Carpinus).

Huckleberry (Gaylussacia).

Hydrangea (all species).

Hypericum Moserianum.

Ilex sp.

Itea virginica.

Japan Pagoda tree (Sophora).

Judas tree or Red bud (Cercis).

Juniper.

Kentucky Coffee tree (Gymnocladus).

Koelrenteria paniculata.

Larch.

Leather leaf (Cassandra).

Leatherwood (Dirca).

Magnolia (all species).

Maidenhair tree (Ginkgo).

Matrimony Vine (Lycium).

Mock Orange or Syringa (Philadelphus sp.).

Mountain Laurel (Kalmia).

Oak (all species).

Papaw (Asimina triloba).

Paulozenia imperialis.

Pearl bush (Exochorda).
Phellodendron sp.

Pine (all species).

Potentilla fruticosa.

Prickly Ash (Xanthoxylun anericanum).

Privet (Ligustrum sp.).

Retinospora (all species).

Rhodotypos kerrioides.

Shepherdia sp.

Silver Bell (Halesia tetraptera).

Smilax sp.

Spice bush.

Spruce (Picea).

Stephanandra flexuosa.

Styrax japonica.

Sweet Pepper bush (Clethra).

Sweet Gum (Liquidambar).

Sweet-scented Shrub (Calycanthus floridus).

Tantarix sp.

Trumpet Creeper (Tecoma radicans).

Trumpet Vine (Bignonia).

Tulip tree.

Umbrella pine (Sciadopitys verticillata).

Wax Myrtle (Myrica cerifera).

Weigela.

White Fringe (Chionanthus).

Wistaria.

Witch Hazel (Hamamelis).

Xanthoceras sorbifolia.

Yellow Jasmine.

Yellow Wood (Cladastris).

Yew (Taxts).

\section{Natural Enemies.}

The native insect parasites of the San José Scale, Anaphes gracilis How., Aphelinus fuscipennis How., and Aphelinus mytilaspidis LeB., which have been recorded from Maryland,* are not very effective in checking the pest in Connecticut, if they attack it at all here. In fact, at various times we have collected

\footnotetext{
* Maryland Agricultural Experiment Station Bulletin No. 57, p. 68, I898.
} 
scale-infested twigs, placed them in glass tubes and stuffed each end with cotton, to see if any parasites could be reared. None were obtained. In examining orchard trees and inspecting nursery stock all over the State we have never observed anything but slight indications that the San José Scale is parasitized in Connecticut. It is a common occurrence to find old shells of the oyster shell scale, each with a small round hole where the parasite had emerged. Not so with the San José Scale.

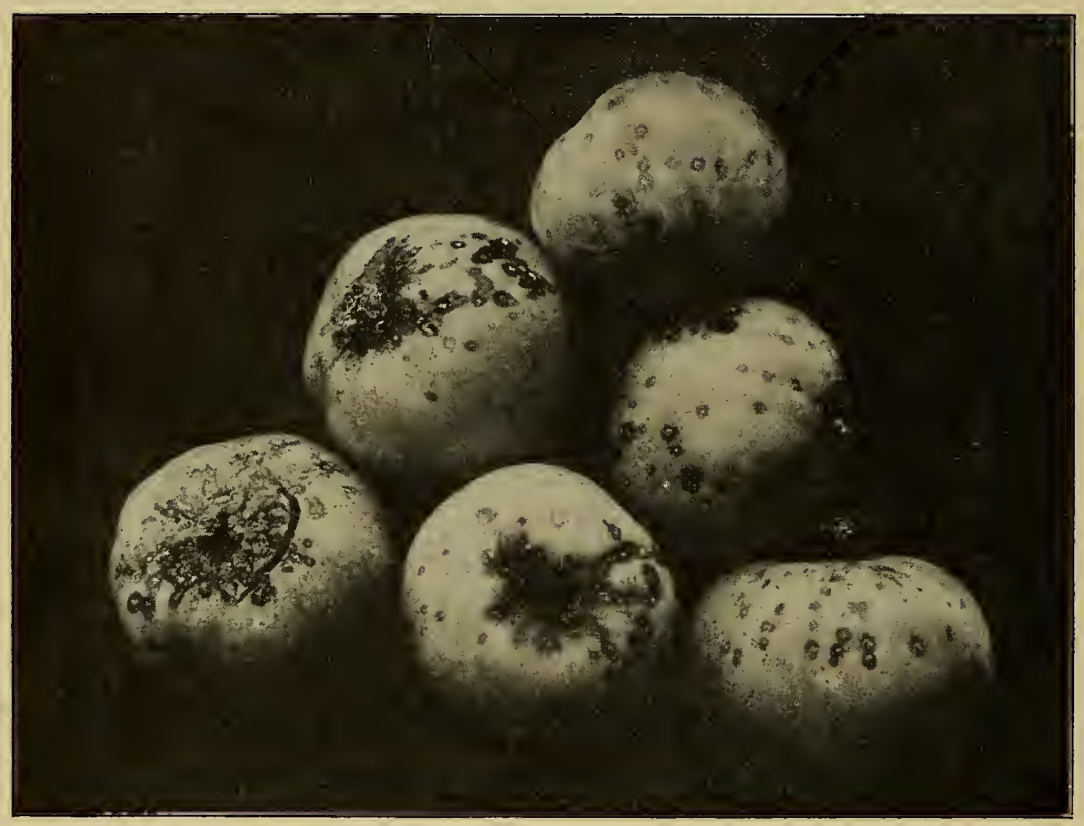

FIG. 8.- Infested Apples showing the discoloration around the insects.

In the South a fungus; Sphaerostilbe coccophila, attacks this as well as other species of scales native to that region. In Connecticut a fungus, Capnodium, sp., is often found on trees which are thickly covered with dead scales. This fungus is evidently a saprophyte, though partially parasitic, and was first observed in rgo2.*

\footnotetext{
* Report of this station for I902, D. 129.
} 
In Connecticut the most important natural enemies of the scale are predaceous and consist of two species of lady beetles known as the twice-stabbed lady beetle, Chilocorus bivulnerus Muls., and a much smaller species, Pentilia misella LeC.

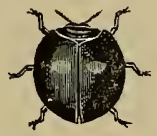

FIG. 9.-The Twice-stabbed Lady-Beetle Chilocorus bivuhnerus Muls. Twice natural size.

The twice-stabbed lady beetle is a moderate check on the San José Scale in some orchards in certain seasons. We have observed it all over the State, where it has been found for many

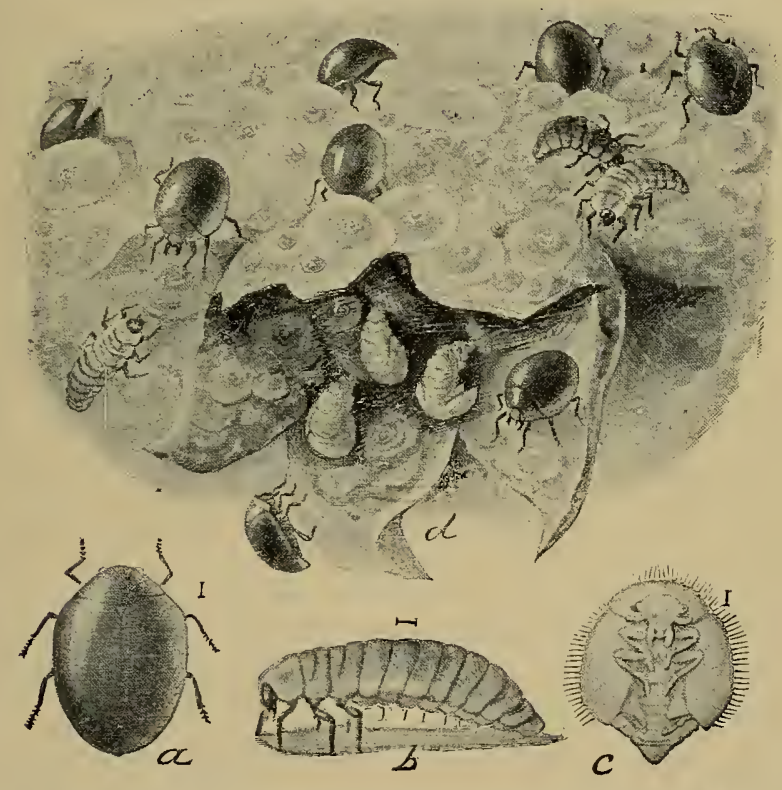

Fig. Io.-Pentilia misella LeC. $a$, beetle; $b$, larva; $c$, pupa; $d$, blossom end of scale-infested pear, showing beetles and their larvæ feeding upon the scales, all greatly enlarged. (After Howard \& Marlatt, Bull. 3, N. S. Div. of Ent., U. S. Department of Agriculture.)

years, and on the whole it cannot be considered as a very important natural enemy of the scale. It is about three-sixteenths of 
an inch long, and black, with two red spots on the back of the wing covers. It is shown in Figure 9.

The other lady beetle, Pentilia misella, is all black and less than one-sixteenth of an inch long. We have also seen this species in different parts of the State, and sometimes quite abundantly on a few trees. It is shown in Figure Io.

None of the enemies mentioned above are important checks to the scale in Connecticut. In fact, all of them together do not materially lessen the numbers of the scales, of which from 25 to 50 per cent. are killed each winter, the climatic conditions being a more important check than all insect and fungous enemies combined.

\section{Control Measures.}

After more than twelve years of experimenting in the Eastern States, the methods commonly practiced at the present time are fumigating with hydrocyanic acid gas to kill the scales on nursery stock when dug for shipment and spraying orchard trees with lime and sulphur mixtures or with oil preparations.

\section{Fumigating Nursery Stock.*}

Each well-equipped nursery is now provided with a tight fumigating house in which hydrocyanic acid gas is generated from the chemicals named below:

Quantity for Each Ioo Cubic Feet of Space-

I oz. (av.) Potassium cyanide, 98-100\% purity.

2 fluid ozs. Sulphuric acid, high grade, $66^{\circ}$ Baume test.

4 " "Water.

The fumigating house should be measured carefully, the cubic contents ascertained, the quantities of chemicals computed and the figures posted in some place convenient for ready reference. The house should be as nearly square as possible, with the stone or earthenware generating jar under the slat floor and near the center. The loose trees should be packed in horizontally with the roots outside and the tops in the center. It is

* For more complete directions about fumigating nursery stock, see Bulletin of Immediate Information No. 3 of this station. 
imperative that the house be supplied with ventilators and with a generating jar which can be reached or operated from the outside. The acid and water should be placed together in the jar, stirring to prevent a too rapid generation of heat. Cyanide may be weighed out and placed in cheese cloth bags, and these kept in tight tin cans or glass jars ready for use. When all is ready, drop the cyanide into the jar, close everything tight, and fumigate for a period between thirty and forty-five minutes. Then ventilate the house thoroughly before entering it.

A house IO $\times 10 \times 8$ feet will be large enough for most nurseries, contains 800 cubic feet, and for each charge requires:

I/2 lb. Potassium cyanide.

I6 fluid ozs. (I pint) Sulphuric acid.

32 “" (I quart) Water.

CAUTION.-Potassium cyanide is one of the deadliest poisons. Do not let it come in contact with cuts or bruises, nor inhale the dust or fumes which rise from it when it is handled.

\section{Spraying Orchard Trees.}

Orchard trees in the Eastern States are not commonly fumigated to rid them of insect pests as are the orange trees of California. The expense would be great on account of their large size. Considerable fumigating has been done, however, in Maryland, and it has been tried experimentally in Connecticut. The common practice is to spray the trees while dormant with either some form of the lime and sulphur mixture or one of the oil preparations. Various sprays have been developed, recommended and used. At first whale oil soap was advised. Lime and sulphur was given a trial by the Bureau of Entomology at Washington in I894 and pronounced ineffective, and was not again tried until about 1900. Meantime kerosene and crude oil were used, the latter tried extensively in New Jersey, with success. Pumps were devised for mixing oils with water under pressure, the amounts being determined either by different-sized openings or by separate cylinders of different size or length of stroke. These pumps are not used extensively at the present time because they are not to be depended upon to give the proper proportions. If 
the packing wears slightly, the proportions are changed, and in practice it is not uncommon to find the apparatus throwing at times almost clear water, which will not kill the scales, and at other times so much oil that the trees are injured by it.

Various soap emulsions and rosin washes were tested and again in I900 the lime, sulphur and salt mixture was investigated and made the subject of extensive experiments by the Bureau of

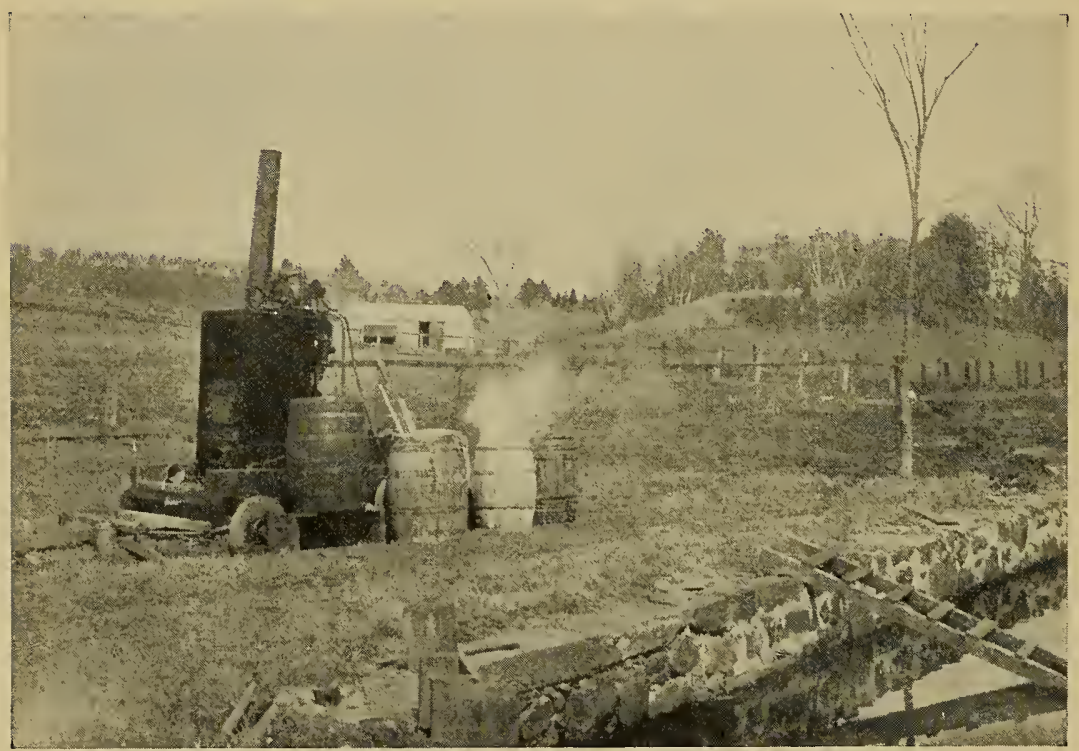

FIG. Ir.-Boiling the lime and sulphur mixture. A portable engine with boiler is placed near the orchard where water can be obtained. Steam is conveyed to the barrels through common rubber hose.

Entomology and various agricultural experiment stations in the Eastern States. This time better results were secured, and the work was followed through several seasons, resulting in several modifications of the mixture, and the best methods of preparing it were worked out. Thus it was found that salt neither adds to the effectiveness nor the adhesiveness of the mixture. New York, New Jersey, Maryland, Georgia, Illinois and Connecticut were some of the states that were foremost in the demonstration of the practicability of the lime and sulphur mixtures in the 
East and the development of the formulas for preparing them. Some of the methods of making without boiling are not now in vogue because of the commercially prepared mixtures that are now on the market. The development and perfecting of the "soluble" or miscible oil mixtures during the past few years has enabled us to spray with an ordinary pump oil emulsions which can be readily diluted with water. These have in part supplanted the use of the lime and sulphur mixtures, though after using them many commercial orchardists are now returning to the lime and sulphur preparations, especially for peach trees, on account of their great fungicidal value. The home preparation of the "soluble" or miscible oils has been worked out, but this is too complicated for general practice, and we do not advise it except in the large orchard where materials can be purchased in quantity. Even then it will often be found cheaper to pay the manufacturer for mixing, and a more uniform product will be obtained.

\section{Homemade Lime and Sulphur Mixtures.}

For making the regular boiled mixture we use fresh whitewash or finishing lime, nearly free from magnesia, and finely ground sulphur known as light sulphur flour or the sublimated product called flowers of sulphur. The boiling may be done in a kettle over a fire or in an open barrel with steam from a boiler, as is shown in Figure II. We advise the following proportions:

20 lbs. Lime.

I4 lbs. Sulphur.

40 gals. Water.

The lime should be started slaking, then add the sulphur and with constant stirring add enough water to cover, and boil for about one hour. Then strain into the pump barrel and dilute with cold water to make forty gallons. The mixture should then be applied at once to the dormant trees. If allowed to stand over night, crystals form in the bottom of the barrel which clog pump and nozzles, and it is necessary to heat it up again before using.

There are several formulas for making the mixt11re without boiling, but the space here is too limited to discuss them. In 
general, we advise the orchardist either to make the boiled mixture or to purchase the ready-prepared commercial mixture which is now sold on the market-a brand being made by nearly every manufacturer of insecticides.

Commercial Mixtures of Lime and Sulphur.

For the last two years a number of different makes of limesulphur mixtures have been made and sold. We have not tested

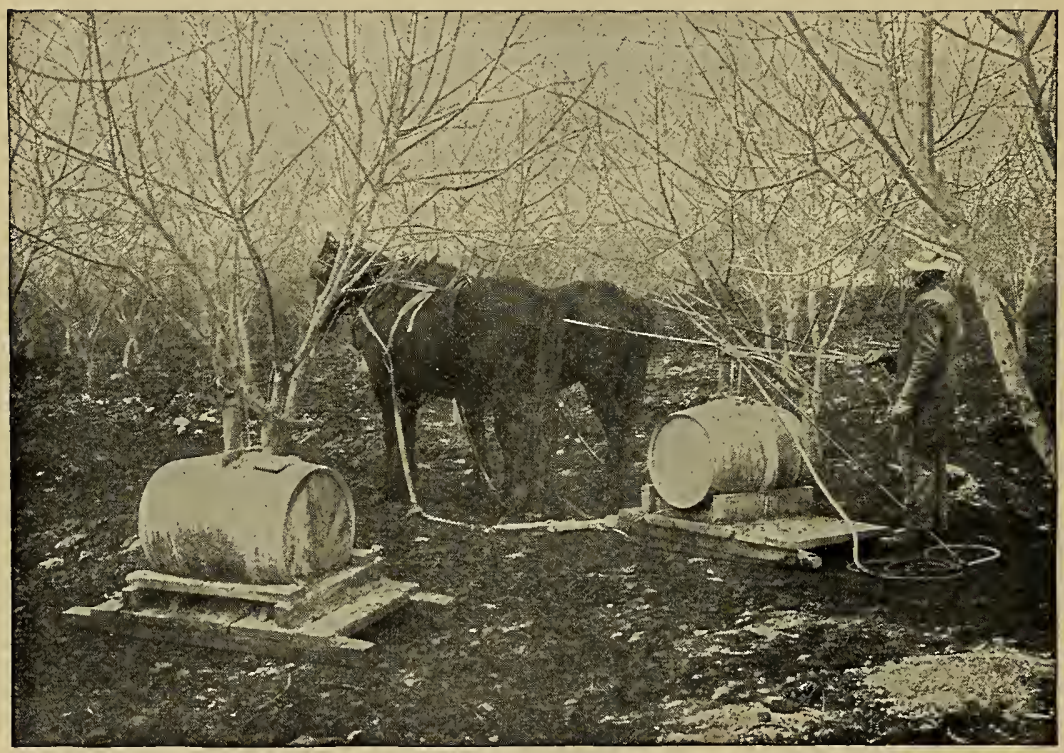

FIG. 12.-An excellent outfit for a rough orchard is shown at the right.

them all, but some of them have been used by us and also in large quantities by Connecticut orchardists. The results have been satisfactory. Such preparations are clear liquids of amber color. The sulphur is all dissolved, no crystals form on standing, and there is no sediment to clog pumps and nozzles. It is only necessary to dilute nine or ten times with water, according to directions. It can be purchased in any quantity from one gallon up to a car load lot, and is less expensive than most of the oil preparations and only slightly more so than the homemade limesulphur mixture. 
Lime and sulphur mixtures may be applied to the dormant trees any time between November Ist and April I5th in Connecticut, and there is no danger whatever of injuring the trees. It is an excellent fungicide, the best remedy for peach leaf curl, and by still further dilution, say thirty times, the commercial preparations are recommended for use as a summer fungicide spray.

\section{"Soluble" oR Miscible Oils.}

Several preparations of this type are on the market, "Scalecide" being one of the oldest and best known. These oil preparations are really emulsions and most of them contain a vegetable oil and an alkali which when mixed together with mineral oils in the right proportions will hold the latter as an emulsion when diluted with water. Some also contain fish oil and carbolic acid. Those who wish to make up their own miscible oils should consult the publications of Penny* and Jarvist and the report of this station for 1908 , page 837 , but the average orchardist had better purchase a ready-made oil mixture than to attempt to make it himself. With all oil preparations there is more or less separation of the ingredients on long standing, so that the entire contents of each original package should be mixed very thoroughly before any portion is removed to mix with water. If this is not done, the oil preparation will not mix properly with water and is liable to injure the tree.

Never use any miscible oil preparation that refuses to mix with water.

\section{Lime and Sulphur Mixtures vs. Miscible Oils.}

The advantages of the lime and sulphur mixtures are the cheapness, effectiveness in killing scales and excellent fungicidal qualities. If the bark has been well coated with this mixture the scales do not become established upon it the following season as readily as when the oil mixtures are used. There is no injury to the trees, and the rubber hose is not ruined.

* Bulletins Nos. 75 and 79, Delaware Agricultural Experiment Station, 1907. Bulletin No. 86, Pennsylvania Agricultural Experiment Station, I908.

$\dagger$ Bulletin No. 54, Storrs (Connecticut) Agricultural Experiment Station, 1908. 
The disadvantages are that it is caustic and somewhat unpleasant to handle, and if the spray strikes the light-colored paint of a fence or building it discolors it, forming black spots, which disappear after a few weeks. It gives the trees a whitish color, slightly disfiguring them. Its penetrating qualities are not as great as in the oil preparations, and on old apple trees having much rough bark the latter are often preferable. The pubescent terminal twigs of the apple also can be covered more readily with the oils than with the lime and sulphur, which tends to gather in drops and roll off. Where apple trees are sprayed with the lime and sulphur mixture it is a common experience to find no scales on the old wood but enough on the new twigs to infest the fruit and spot it noticeably. The lime and sulphur mixture corrodes slightly the metal parts of the pumps.

Advantages of the oil preparations are that they are pleasant and not caustic to handle, and will not disfigure the trees, shrubs, or painted buildings. They do not clog or corrode pumps or nozzles, and they penetrate nicely. A gallon will cover more surface than a gallon of lime and sulphur.

Disadvantages are that the ingredients separate on standing and evaporation sometimes prevents the proper mixing with water. Injury has been caused to trees by the use of such preparations not properly mixed. Scales will set more readily on the bark after the use of the oil mixtures than where lime and sulphur is used. It is more expensive and is not as valuable as a fungicide. The oils affect rubber, and the hose is quickly ruined.

\section{How to Treat an Infested Orchard.}

Suppose we have a badly-infested orchard of peach or apple trees, how shall we treat it? This is a problem confronting many commercial fruit-growers in Connecticut to-day, as well as a large number of persons who have small orchards for the home supply.

In the light of our present knowledge of what has been accomplished in Connecticut and elsewhere the following treatment seems to be the proper one to apply.

Remove the worthless trees. It will not pay to treat them. 
Cut back severely, especially the branches that have lost a portion of their vitality because infested. This will enable the trees to make a stronger growth in the spring and reduce the area to be covered with the spray. The remaining portion being nearer the ground can be sprayed more economically than the ends of the twigs. Burn all branches cut off; fire is an effective destroyer of insects and fungous diseases.

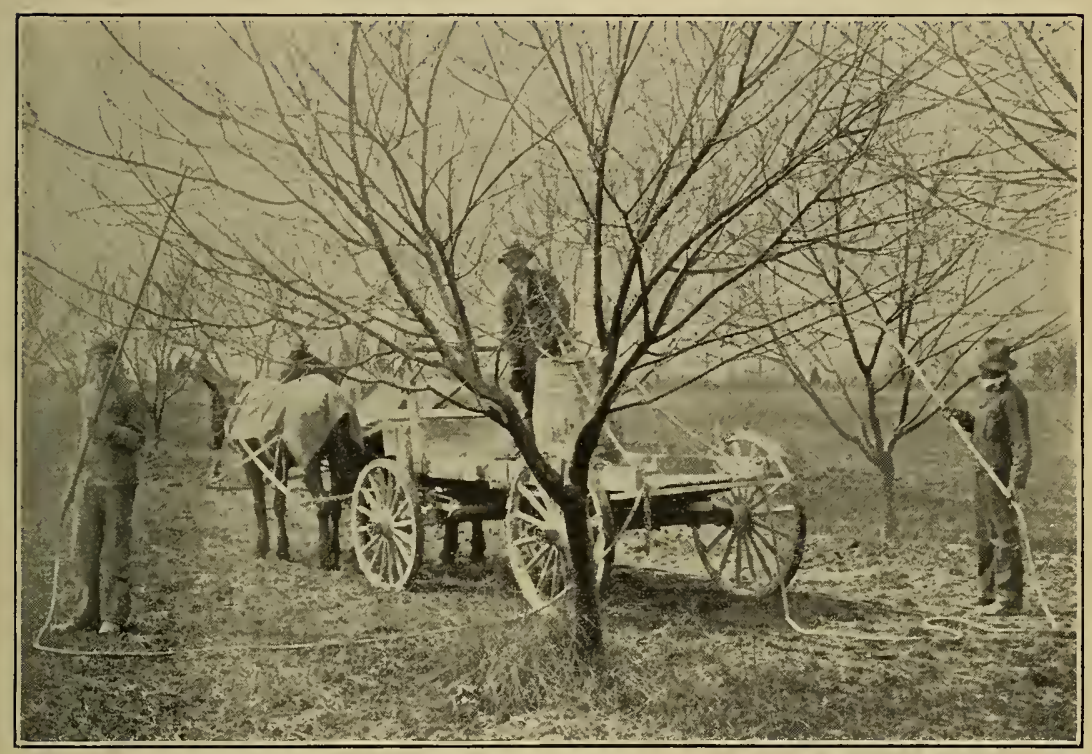

FIG. I3.-Outfit mounted on wagon.

Spray the pruned trees during the winter months with the lime and sulphur mixture, or one of the miscible oils, taking pains to coat thoroughly all portions of the trunk from the ground to the ends of the branches.

Peach, plum or pear trees, which have smooth bark, should be sprayed with lime and sulphur, which kills the scale and is also a good fungicide; oil preparations are often preferable on rough-barked apple trees. Badly infested trees sometimes need to be sprayed twice the first season, in which case the oil may be applied in November as soon as the leaves fall and lime and sulphur in the spring. The oil mixtures should be diluted with 
not more than fifteen parts water. Both lime and sulphur mixtures and oil preparations may be used in the fall.

When growth begins, fertilize liberally, spray apple trees to preserve the foliage, and cultivate thoroughly to promote the vigor and health of the trees.

\section{SUMIMARY.}

The San José Scale appeared and caused much destruction of fruit trees in California thirty years ago. China is probably the country of its origin.

It was first found in the Eastern States in I893, and now occurs in nearly all the states of the Union except, perhaps, the extreme northern ones.

The scale was brought into Connecticut on nursery stock in the early nineties, but not discovered until 1895 . Seventy-eight infested localities had been found in this State and twenty-five states had passed inspection laws up to July Ist, I90r, when the present Insect Pest Law went into effect. Since that time the scale has spread to nearly every portion of the State and forty-five states and territories now have laws regarding the inspection and transportation of nursery stock.

The scale is inconspicuous and is seldom noticed until the vitality of the tree is impaired, at which time the bark is usually coated with a roughish grey substance. The reddish discoloration may be found around each individual. Leaves and fruit are also attacked. The female scale is nearly circular in outline, while the male is somewhat elongated. If the scale is lifted the insect proper may be seen underneath, by the aid of a lens, as a yellow object.

The vitality of the tree is gradually lessened by the hordes of insects sucking its sap. The pest is seldom noticed until some of the twigs die. Entire trees have been killed in four years in Connecticut by the scale.

Though the young scales crawl short distances, they are usually carried from one tree to another by other insects, or upon the feet of birds. They may also be carried uponfallen leaves, fruit, or the clothing of persons, etc.

The full-grown female scale gives birth to living young, which crawl about for a short time and then settle upon the bark. There are three or four generations each season. They feed by sucking the juices from the tree. Each female may produce from less than one hundred to six hundred young.

Common fruit trees and plants of the rose family are usually preferred by the insect, but it is liable to attack other kinds that may be growing near infested trees. A list of food plants may be found on page II.

Natural enemies are not very effective in holding the scale in check in Connecticut, the most important being two species of lady beetles.

In nurseries the stock is fumigated with hydrocyanic acid gas when dug for shipment. Orchard trees are sprayed while dormant with the lime and sulphur mixture, or with one of the "soluble" or miscible oils diluted at the rate of one part in fifteen parts of water. 


\section{University of Connecticut Libraries}


